\title{
The Acquisition of Indoensian Verbs and Nouns by Two Years Old Batak Mandailing Children
}

\author{
Ahmad Rozik Harahap ${ }^{1, *}$ Siti Aisyah ${ }^{2}$ Anni Holila Pulungan ${ }^{3}$ \\ ${ }^{1}$ English Applied Linguistic Study Program, Post-Graduate, State University of Medan \\ ${ }^{2}$ State University of Medan \\ ${ }^{3}$ State University of Medan \\ *Corresponding author. Email: rozikkacamata@gmail.com
}

\begin{abstract}
The research was about the acquisition of Indonesian verbs and nouns by Batak Mandailing Children at Two Years Old. A. The objectives of the research were to find out types of verbs and nouns acquired by Mandailing Batak Children. This research conducted by the qualitative research and the research design of this research is crosssectional design. The data were acquired by observation by recorded the utterances made by children in natural context. The data collected were analysed by interactive models by Miles and Huberman and Saldana Models. The subject of the research were 2 children from the same age and gender. The result of the research is show that the types of verbs and nouns the child produces are the types of verbs in the basic form and types of nouns in the basic form. Based on this finding, there was suggestion in this study, children were only able to acquired basic form of verb and basic form of noun, at the age of 2 they should be able to said words in the form of derived and empowerment, meaning that in this research the subject was still mini in acquiring words so parents are advised to build intensive communication relationships with children to helps the child's vocabulary growth as a provision so that children can be skilled in language.
\end{abstract}

Keywords: acquisition, verbs, nouns, children.

\section{INTRODUCTION}

Language is an important instrument for communicating with other people or it can be called as a tool of communication. Language acquisition is a study which tells us about the psychological and intellectual functions of children when they are adults.

Children use verb and noun in doing conversation and almost every children will guide by family for good communicate.

A study conducted states that children begin to produce recognizable words of their language about one year of age [2]. By 18 to 20 months, they typically have acquired approximately 50 words and by the age of two, the average children know 200-300 words. It is believed that by the time the children at the age of two, they typically have acquired hundreds of vocabularies and having the base grammar without transformation.

In a study of children aged fourteen to twenty-four months give an average of fifty words at twenty months and 186 words at twenty-four months [9]. Around the age of two, the children combine words and gestures and produce their first words combination [4]. The children still have difficulties in producing longer utterances, for example for two-word combinations. Gestures appear to help the children to communicate before they can pronounce the longer phonological sequences required for combining words.

\section{REVIEW OF LITERATURE}

Through hearing, children do not speak [6]. Listening to adults' speech gives them two models. The first model is model of behaviour where a child sees that speaking is a way of communicating. Mind the second model is model of a language in which the surrounding language furnished a child with elements that characterized the structure of the language to be learns as well as its vocabulary.

Linguistic approach in language acquisition is much influenced which slating that there should be a mechanism or an advice that can deduce a grammar from a limited set of utterances; they named these devices as language acquisition device [10]. The linguistic approach 
focuses on the language itself as the object of study viewing it as abstract systems that underlines linguistic behavior.

During this period, children can begin to produce words, even though they cannot pronounce them perfectly. In this period, children still have difficulty pronouncing some letters such as $\mathrm{r}, \mathrm{s}, \mathrm{k}, \mathrm{j}$, and $\mathrm{t}$.

States about 1,6 year, the child will start to put together two successive single words, e.g. "momma....nnum" which means " moma minum " [5]. In these ages 1;5 and 1;7, the child produces words for object increasingly [4] and also the period during which one word or two word sentences are beginning to be used and symmetries observed in frequency and after this period, it may indicate a recycling of the developmental process. [8]

In 2018, Andini conducted research about the process of acquiring bahasa Indonesia for the 0-2 years old children in term of phonology and morphology. The research was conducted in one housing resort in Rancak city, the district of Praya, central Lombok namely BTN Pujawan Permai. The reason is that because the people living in this housing resort come from variety of places. In collecting data the researcher applied theory of psycholinguistic using field notes and interview the subjects. The results are as follows: First, phonologically, the 0-2 years old children are still not able to pronounce some phones clearly such as the fricative consonant [r] which they are changed into lateral consonant [1]. Second, morphologically, children are able to use nouns, adjectives, verbs and some simple phrases correctly event their pronunciation is still not very clear.

\section{RESEARCH METHOD}

The study conducted qualitative descriptive design. It is descriptive data which the data collected take the different family background children at the same ages. This research described what types of verbs and nouns acquisition among the children of 2 years old develop the word. Then the research took 2 children.

Two children cames from the same high level education background of parents, where MF lives in the extended family in the house which consist of parents, uncles and aunts, meanwhile $\mathrm{H}$ lives in the nuclear family in the house which only consists of parents and housemaid. Then, the data of this research were the utterances of the two years old children in process of acquiring the language. The data of this research were collected by using observation The observation sheet was use to know the children activity in uttering the words.

\section{RESULTS}

The results of the data analysis showed the Acquired of Verbs and Nouns By Two Years Old Batak Mandailing Children. In this research, the subjects of $\mathrm{MF}$ and $\mathrm{H}$ acquired several words. Based on these few words, the researcher saw that the words they acquired were verbs and nouns. Meanwhile based on the acquisition of the resulting words, the researcher divided them into several types, here are the types of acquisition of verbs and nouns based produced by MF and $\mathrm{H}$ :

\section{TYPES OF VERBS AND NOUNS}

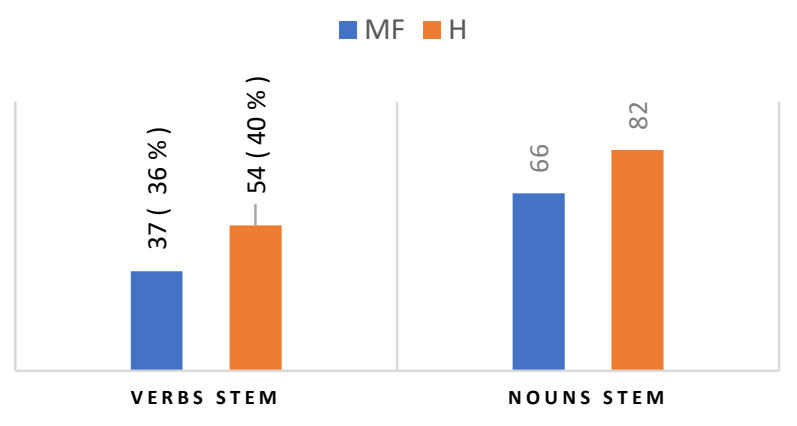

Figure 4.1. Percentage of Types of Verbs and Nouns Acquired

From the figure data above, it can be concluded that the total verb acquired by MF is $37(36 \%)$ verbs and the most dominant verb is the basic form of verbs form while, which consists of the verb derived and compound not found in the MF uttrered. Meanwhile, the most dominant noun uttered by subject MF is the basic form noun with a total of $66(64 \%)$ nouns this is because the noun that is pronounced consists of 1 nouns in the basic form.

The data above also shows that the total verbs obtained by subject $\mathrm{H}$ were $54(40 \%)$ and the most dominant verbs were the basic form verbs. Meanwhile, the most dominant acquired by subject $\mathrm{H}$ were the basic form of noun with total $82(60.3 \%)$ this is because the acquired noun consists of 1 basic form nouns.

The subjects in this study were MF and $\mathrm{H}$, they were two year old Mandailing Batak children. MF is an active child and besides that he wants to talk to other people he meets the first time and he is not shy to talk to them. $\mathrm{H}$ is a shy kid and besides that he doesn't want to talk to other people he meets the first time and he just wants to talk to people he knows well like his parents, baby sitters or he will talk to himself imitating videos on his cellphone.

MF in this study was able to produce 103 nouns and subject $\mathrm{H}$ was able to get more nouns than MF with a total of 136 words so that the difference in nouns between MF and $\mathrm{H}$ was 33 words. 


\section{DISCUSSION}

The findings in this study was that $\mathrm{H}$ gots more words than MF, meanwhile when viewed from the social background factors that support MF. MF lives in a large family in the house. MF lives with parents (father and mother), uncle and aunt. There are so many people around MF, this has a good impact on MF because MF always communicates with family members around him.

In addition, although Mf often communicates with family members and $\mathrm{H}$ often watches videos, Mf and $\mathrm{H}$ only got a few verbs because nouns was more dominant in their acquisition. Besides that, it happens because nouns are easier to remember than verbs. In addition, nouns are seen more at home and are more often conveyed than verbs.

Even though $\mathrm{H}$ has more word mastery than $\mathrm{MF}$, if seen from its pronunciation, MF is better at pronouncing nouns and verbs than $\mathrm{H}$. However, in individual development there may be some differences between one child and another due to other factors (environment) which intervenes.

The findings about producing unclear meanings and pronouncements such as omissions and substitutions because their parents always introduced them to wrong pronunciations, the subject's parents talked and played with them.

this research is related to the types of verbs and nouns acquired by the two year old Mandailing Batak Child. there are four types of verbs the are basic form of verbs, derivative form of verbs, compounding form of verbs, and verbs of empowerment [6]. There are two types of noun, the are basic form nouns and derivative form of nouns [1]. In addition, in the early lingual period (1-2.5 years) children can begin to produce words, even though they cannot pronounce them perfectly [3]. At this time children still have difficulty pronouncing some letters such as $\mathrm{r}, \mathrm{s}, \mathrm{k}, \mathrm{j}$, and $\mathrm{t}$.

Based on the findings in this research, MF acquired 103 words consisting of 37 verbs and 66 nouns, while $\mathrm{H}$ acquired 136 words consisting of 54 verbs and 82 nouns. based on data at the acquisition of verbs and nouns, the subjects $\mathrm{MF}$ and $\mathrm{H}$ both acquired types of basic form of verbs and basic form of nouns. then, in this study subject $\mathrm{H}$ acquired more total words when based of theory that children who often communicate with their parents or environments such as MF will acquire more words, but in this research subject $\mathrm{H}$ gets more words and has more difficulties in the pronunciation of word. This is because subject $\mathrm{H}$ is watch some video so there are many words from the video but in the language acquisition he is not guideded by his parents in acquiring the language so that the language he acquire have many mistake like unclear word and omission.

The discussion are related to theory and some are not related to theory. The related to the findings in this research are that the pronunciation of words at two years of age is still difficult to pronounce the letters $r, s, k, j$, and t. Especially in subject $\mathrm{H}$ there are more complexities in pronouncing the pronunciation, such as for example bayal for bayar (pay), beyok for belok (turn), ntak for minta (ask), and cimpan for simpan (save). This is caused to the busyness of the parents and the lack of understanding of the parents about the effective time in acquiring children's language, causing some of the children's language acquisition or some errors in language pronunciation compared to their peers or subject MF

\section{AUTHORS' CONTRIBUTIONS}

The findings of the research are expected to add up new horizons in the study of language acquisition in children aged two years old. In addition, hopefully, the findings will explore the new ideas for other researchers in investigating the language used in social context along with its functions in society itself, and also be able to give much contributions and insights to apply linguistics particularly in English which can be used as a reference for the similar study with different focus or object in the future. Briefly, the findings can add up more horizons to linguistics and also as a guide line for other researchers to conduct the further research related to language acquisition study

\section{ACKNOWLEDGMENTS}

Researchers would like to express deep gratitude to anyone involved in helping in the form of support and guidance related to the completion of this research, especially to Dr, Siti Aisah Ginting, M.Pd, Dr, Anni Holila Pulungan, M.Hum, Dr, Rahmad Husein, M.Ed, Prof, Amrin Saragih, MA., Ph.D and also Prof Dr, I Wy Dirgeyasa, M.Hum who have helped the author finishing this research, and thanks to Annual International Seminar on Transformative Education and Educational Leadershi (AISTEEL) 2020, and the reviewers who have provided the opportunity for the author to share this research in terms of helping author, so that this research can be completed properly.

\section{REFERENCES}

[1] Alwi, H. et al. Tata Bahasa Buku Indonesia. Jakarta: Balai Pustaka. 2003.

[2] Baret, M.D. Early Lexical Development. Oxford: Blackwell. 1995. 
[3] Chaer, Abdul. Linguistik Umum. Jakarta: Rineka Cipta.2003

[4] Clark, E.V. First Language Acquisition. Cambridge: University Press. 2003.

[5] Dardjowidjoyo, S. ECHA : Kisah Pemerolehan Bahasa Anak Indonesia. Jakarta: Grasindo jaya. 2000.

[6] De Boysson, B.B. How Language Comes to Children. Massachusetts: MIT Press. 1999.

[7] Depdikbut. Pedoman Istilah Bahasa Indonesia. Jakarta. 2006.

[8] Menyuk, P. The Acquisition And Development of Language. Massachusetts: Massachusetts Institute of Technology. 1971

[9] Nelson, K. Structure and Strategy In Learning To Talk. Hillsdale, N.J: Leurence ErlbaumAssociates. 1973

[10] Paivio. A and Begg. Psychology of Language. New Jersey : PrenticeHall. 1981

[11] Yule, G. The Study of Language : Fourth Edition. New York : Cambridge University Press. 2010 